\title{
An update on osteoporosis research: effect of calcium plus vitamin D supplementation
}

\author{
Lincon Chandra Shill ${ }^{1}$, Nafisa Habib Purba ${ }^{1}$, Marjia Sultana ${ }^{1}$, \\ Towhid Hasan $^{1 *}$, Mahmudur Rahman ${ }^{1}$, Nahid Sultana ${ }^{2}$
}

\begin{abstract}
${ }^{1}$ Department of Food Technology and Nutrition Science, Noakhali Science and Technology University, Noakhali3814, Bangladesh

${ }^{2}$ Department of Gynaecology and Obstetrics, Kurmitola General Hospital, Dhaka-1206, Bangladesh
\end{abstract}

Received: 27 June 2019

Accepted: 13 August 2019

\author{
*Correspondence: \\ Towhid Hasan, \\ E-mail: towhidhasan07@gmail.com
}

Copyright: (C) the author(s), publisher and licensee Medip Academy. This is an open-access article distributed under the terms of the Creative Commons Attribution Non-Commercial License, which permits unrestricted non-commercial use, distribution, and reproduction in any medium, provided the original work is properly cited.

\begin{abstract}
Osteoporosis is the most common systemic skeletal disease characterized by increased bone fragility. There lies an incongruity among research regarding combined supplementation of calcium (Ca) plus vitamin D and loss of bone health. Hence, the present review is aimed to highlight the current development of osteoporosis research and try to solve the inconsistency among the present knowledge. Electronic databases like PubMed, Cochrane Library, and EMBASE were searched from their inception to December 2018 using terms "calcium," "vitamin D," and "osteoporosis." A systemic approach was followed to reach a final of 23 studies assessing the synergetic effect of calcium and vitamin D on osteoporosis and fractures risk. Among the included studies, nineteen have revealed that calcium and vitamin D decrease bone resorption, reduce the incidence of fractures, increase bone mineral density (BMD) and overall bone health. However, no significant osteogenic response was reported in five trials after supplementation with calcium and vitamin D together. Osteoporosis results in a reduced quality of life, increased disability-adjusted life span, and big economic burden to health care systems of countries. Early diagnosis before the occurrence of fractures and by assessing BMD and with early treatment, osteoporosis can be prevented. It is not entirely possible to draw a conclusion regarding beneficial effects of calcium plus vitamin D supplementation; future research based on the fundamentals of bone biology focusing on molecular genetics, and influencing factors of the acquisition of bone mass during growth and bone loss can alleviate present controversies.
\end{abstract}

Keywords: Osteoporosis, Calcium, Vitamin D

\section{INTRODUCTION}

Ageing is a common phenomenon that happens with every human worldwide, and with aging, a gradual loss of bone mass occurs resulting in osteoporosis. ${ }^{1}$ Osteoporosis is a chronic metabolic bone disease characterized by low bone density and microarchitectural deterioration of bone tissue with a consequent elevation in bone fragility. ${ }^{2}$ Since bone loss remains asymptomatic and early osteoporosis is not usually diagnosed, osteoporosis is often considered a 'silent disease'; it does not become clinically evident until fractures occur. Advancement of age is associated with loss of bone density and rates of fracture increase markedly with age, giving rise to significant disability and some deaths. ${ }^{3}$

Osteoporosis is the most common systemic skeletal disease in humans, representing a major public health problem. Just like hypertension is considered a risk factor for stroke, osteoporosis is for fracture. ${ }^{3}$ It affects an enormous number of people, of both sexes and all races, and its prevalence will increase as the population ages. It 
was estimated that, globally, the number of patients with osteoporotic hip fractures is over 200 million. ${ }^{4}$ According to WHO, osteoporosis is three times more common in women than in men. ${ }^{3}$ In Europe and the United States, $30 \%$ women are reported to be osteoporotic, and a prediction was made that $40 \%$ post-menopausal women and $30 \%$ men will experience an osteoporotic fracture in near future of their lives. ${ }^{5-7}$

Osteoporosis can be classified as either primary or secondary by considering the factors affecting bone metabolism. In primary osteoporosis, loss of bone mass occurs in both males and females due to the normal aging process. Bone loss in secondary osteoporosis may result from different types of medications, nutritional deficiencies and chronic medical conditions. ${ }^{8}$

Although the causes of osteoporosis are multifactorial, the most significant are decrease in bone mass, structural deterioration, and enhanced frequency of falls. ${ }^{3}$ It is widely recommended to use calcium plus vitamin D supplementation for the management of osteoporosis and subsequent fractures; however, recent data shows some inconsistencies in findings. Whereas some studies show that calcium along with vitamin $\mathrm{D}$ supplementation minimize the risk of fractures, others argued the statement showing no effect. In recent years, a growing body of scholars have risen a concern that calcium supplementation may be harmful, so some healthcare providers are unwilling to use calcium supplements. ${ }^{9}$ On the other hand, a number of evidences suggest the role of vitamin $\mathrm{D}$ to uphold bone health, and healthcare providers are amplifying their research to assess vitamin D status among the population. However, all of these statements are suggestive, many questions are yet to be answered. Hence, the present review was undertaken to provide a better understanding about recent development in osteoporosis research, and whether calcium and vitamin D supplementation together can really benefit individuals with osteoporosis and at risk of becoming osteoporotic.

\section{METHODS}

\section{Search strategy}

A literature search of the electronic databases of PubMed, Cochrane Library, and EMBASE was carried out from their inception until December 2018. The Medical Subject Headings (MeSH) terms were "calcium," "vitamin D," and "osteoporosis." The reference lists of full articles were also reviewed. Only English language articles were included. The search strategy can be found in Supplemental file 1.

\section{Study selection criteria}

We only included the randomized controlled trials conducted on humans that met the following criteria:

\section{Participants}

Both healthy individual with no known disorders of bone metabolism or vitamin D deficiency, or primary osteoporotic participants.

\section{Intervention}

Both vitamin $\mathrm{D}$ (oral or intramuscular vitamin $\mathrm{D}_{2}$ or vitamin $\mathrm{D}_{3}$ at any dose and frequency), and calcium (oral calcium salt preparations at any dose and frequency).

\section{Outcome}

Non-vertebral fractures, proximal humerus fracture (PHF) and hip fractures, BMD, or incidence of fall.

Studies were excluded if there were enrollment of pregnant women, assessment of the efficacy of only calcium supplementation or only Vit D supplementation on osteoporosis; no treatment, placebo, or lower- or higher-dose vitamin D or calcium regimens as control; short-term ( $<1$ month) treatment; no outcomes of interest for our study.

\section{Data extraction and quality assessment}

Two reviewers independently investigated titles, abstracts, and full-text articles, and extracted qualitative and quantitative information from eligible articles, including author and year of study, geographic study location, subjects, treatment modality, duration of followup, exposure metric units, number of incidents, and inferences based on analytical comparisons. Any disagreements between them were resolved by consensus. For each included study, one reviewer extracted information about study design, subjects, intervention, and outcomes, and a second reviewer evaluated about completeness and accuracy of the study.

\section{RESULTS}

A total of 568 studies were initially searched in this study. Of these, 43 full articles were shortlisted for eligibility assessment. Among the 43 articles, 10 studies were excluded due to irrelevant intervention and 9 studies because the outcomes were not of interest to our study. Finally, 23 eligible articles were included in this study. The results have been shown in Figure 1.

In the present review, 23 randomized controlled trials (RCTs) were included to ascertain the association between supplementation of calcium and vitamin $\mathrm{D}$ on osteoporosis. The interventions lasted from 3 months to 7 years enrolling a minimum of 11 subjects to 36,282 subjects. Participants received calcium with a daily dose of $300-3000 \mathrm{mg}$ and vitamin D $400 \mathrm{IU} /$ day to $\sim 14300$ IU/day. 


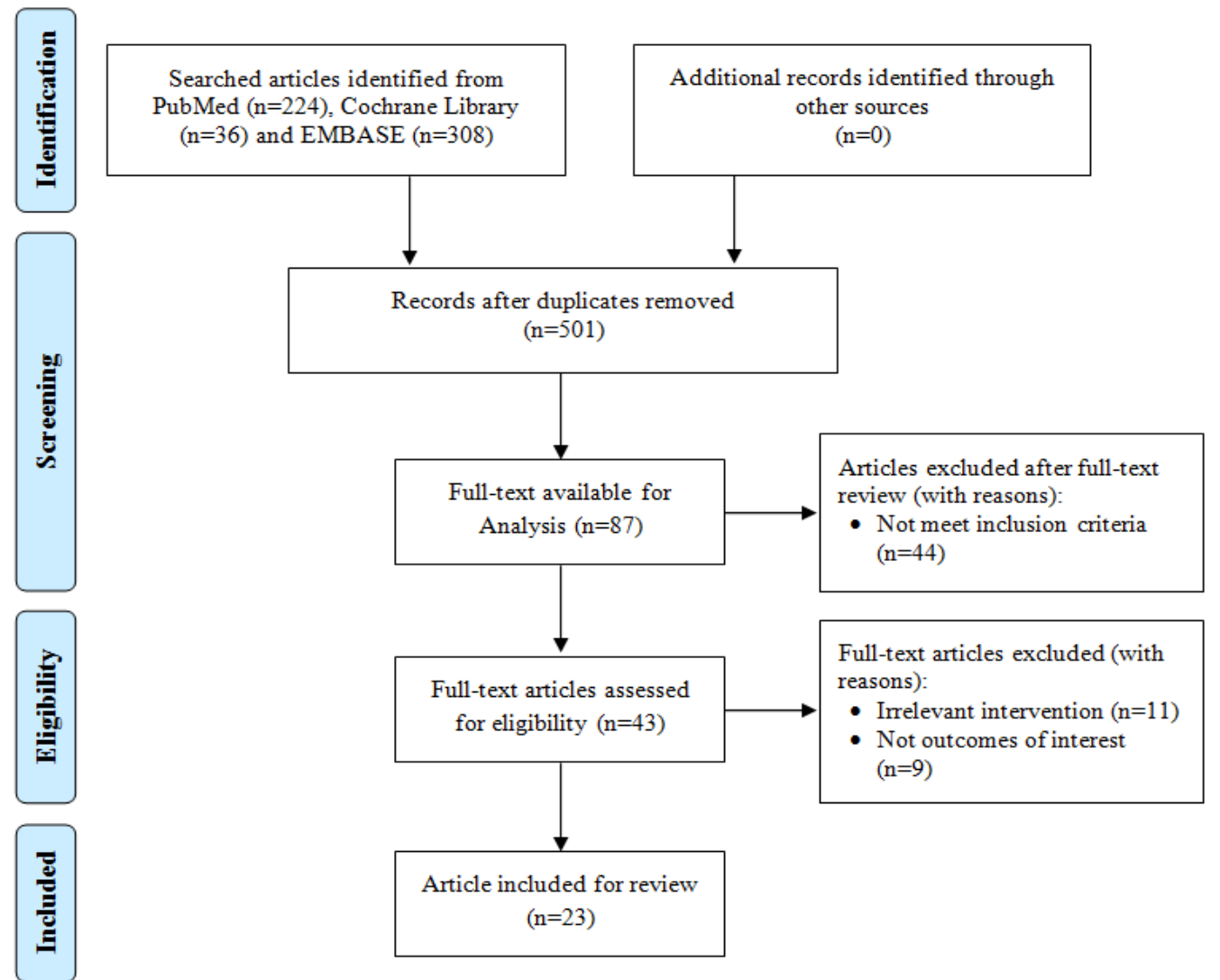

Figure 1: Selection of eligible studies.

Among the included studies, two studies revealed that oral Ca and vitamin D therapy in primary osteoporosis decrease bone resorption. Another eight studies concluded that dietary supplementation with calcium and vitamin D moderately reduces the incidence of nonvertebral fractures, PHF, and hip fractures. Supplementation of both calcium and vitamin D has been found to be beneficial for increasing BMD and improving overall bone health in the eight RCTs. However, no significant osteogenic response was found in the five RCTs after supplementation with both calcium and vitamin D (Table 1).

\section{DISCUSSION}

It is now well recognized that vitamin $\mathrm{D}$ promotes calcium absorption in the gastrointestinal tract and assist in maintaining adequate serum calcium concentrations to enable proper mineralization of the bone. Vitamin D is indispensable for bone growth and bone remodeling by osteoblasts and osteoclasts. 1,25-dihydroxycholecalciferol, the active form of vitamin D metabolite opens up calcium channels in the gut which can further stimulate the formation of calcium binding protein in the intestinal cell, and thereby increases the absorption of calcium from the gut. ${ }^{10}$ In this way, optimal circumstances for bone mineralization are created. Mineralization in itself is a passive process in the present of the sufficient calcium and vitamin D. In the vitamin D deficiency, the 1,25-dihydroxycholecalciferol concentration may drop and less calcium will be available for bone mineralization resulting in the decreased bone loss and finally led to osteoporosis. ${ }^{10}$ Thus, synergistic action of calcium and vitamin $\mathrm{D}$ is crucial for the bone health, particularly to reduce osteoporosis and associated risk of bone fracture.

Identification of strategies to reduce osteoporosis and related fracture risk is imperative, given that osteoporosis and low bone mass is attributed to disability and impaired quality of life of an estimated 53.6 million Americans aged $>50$ years in $2010 .^{6}$ The estimation of the total cost associated with osteoporosis is complex and difficult since it includes the costs of acute hospital care, loss of working days for the affected and the family carers, longterm care and medication. However, it is reported that more than two million fractures associated to osteoporosis occur each year in the United States accounting for more than 19 billion US dollar in annual healthcare costs. ${ }^{11}$ It has been shown in many surveys that many people do not consume recommended amounts of calcium and vitamin D. ${ }^{12,13}$ Both nutrients are substantial for optimal skeletal health throughout the lifecycle: calcium is the dominant mineral in bone, and vitamin $\mathrm{D}$ is important for the efficient absorption of calcium and for adequate functioning of bone cells. 
Shill LC et al. Int J Community Med Public Health. 2019 Sep;6(9):4120-4128

Table 1: Effects of dietary and supplementary calcium (Ca) and vitamin D (vit D) on osteoporosis.

\begin{tabular}{|c|c|c|c|c|c|}
\hline $\begin{array}{l}\text { Authors, } \\
\text { year (ref) }\end{array}$ & $\begin{array}{l}\text { Study } \\
\text { location }\end{array}$ & Subject & Treatment & Duration & Findings \\
\hline Jowsey et al $^{14}$ & USA & $\begin{array}{l}11 \text { patients }(1 \mathrm{M}, 10 \mathrm{~F}) \\
\text { with progressive } \\
\text { osteoporosis }\end{array}$ & $\begin{array}{l}\text { Variable doses of sodium fluoride ( } 30-90 \\
\mathrm{mg} / \text { day) and } \mathrm{Ca}(300-1500 \\
\mathrm{mg} / \text { day })+50,000 \mathrm{IU} \text { of Vit D twice weekly }\end{array}$ & 12 to 17 months & $\begin{array}{l}\text { Significant increase in bone formation }(\%) 10.5 \text { vs } \\
3.0 ; p<0.0005 \text {, and decrease in bone resorption }(\%) \\
10.7 \text { vs } 12.6 ; p<0.05\end{array}$ \\
\hline Riggs et al ${ }^{15}$ & USA & $\begin{array}{l}18 \text { patients }(1 \mathrm{M}, 17 \mathrm{~F}) \\
\text { with primary } \\
\text { osteoporosis }\end{array}$ & $\begin{array}{l}\text { Group A: } 2.0-2.5 \mathrm{~g} / \text { day } \mathrm{Ca}+400 \mathrm{IU} / \text { day of } \\
\text { Vit D } \\
\text { Group B: } 1.5-2.0 \mathrm{~g} / \text { day } \mathrm{Ca}+50,000 \text { units of } \\
\text { Vit D twice weekly }\end{array}$ & $\begin{array}{l}\text { Group A: } 3-4 \\
\text { months } \\
\text { Group B: } 3-4 \\
\text { months and } 12 \\
\text { months }\end{array}$ & $\begin{array}{l}\text { Group A: Significant decrease }(\mathrm{p}<0.01) \text { in bone- } \\
\text { resorbing surfaces } \\
\text { Group B: Significant decrease }(\mathrm{p}<0.01) \text { in bone } \\
\text { forming and bone-resorbing surfaces for both short } \\
\text { and long term }\end{array}$ \\
\hline $\begin{array}{l}\text { Inkovaara et } \\
\text { al }^{16}\end{array}$ & Finland & $\begin{array}{l}327(57 \mathrm{M}, 270 \mathrm{~F}) \\
\text { mean age } 79.5 \mathrm{y}\end{array}$ & $\begin{array}{l}\text { Combinations of Ca carbonate } 3 \mathrm{~g} \text {, Vit } \mathrm{D}_{3} \\
1000 \mathrm{IU} \text {, methandienone } 2.5 \mathrm{mg} \text { and/or } \\
\text { placebos daily }\end{array}$ & 9 months & $\begin{array}{l}\text { Methandienone reduced osteoporotic activity and } \\
\text { increased the muscular mass most effectively } \\
\text { Ca carbonate had the poorest effect }\end{array}$ \\
\hline Chapuy et al ${ }^{17}$ & France & $\begin{array}{l}3270 \mathrm{~F} \\
\text { mean age } 84 \mathrm{y}\end{array}$ & $\begin{array}{l}\text { Ca } 1200 \mathrm{mg} / \text { day+Vit D } 800 \mathrm{IU} / \text { day vs } \\
\text { placebo }\end{array}$ & 18 months & $\begin{array}{l}\text { Significant decrease in the incidence of non- } \\
\text { vertebral fractures: } 66 \text { vs } 97(p=0.015) \text {, and the } \\
\text { incidence of hip fractures: } 21 \text { vs } 37(p=0.043) \text { than in } \\
\text { the placebo group. }\end{array}$ \\
\hline Eriksson et al $^{18}$ & Sweden & $\begin{array}{l}22 \mathrm{~F} \text { (middle-aged) } \\
\text { with post-menopausal } \\
\text { osteoporosis }\end{array}$ & $\begin{array}{l}\text { Treatment group: } 0.5 \mathrm{mg} \text { calcitonin thrice a } \\
\text { week subcutaneously }+0.5 \mu \mathrm{g} / \text { day } \\
\text { calcitriol orally }+0.5 \mathrm{~g} / \text { day Ca orally. } \\
\text { Control group: } 0.5 \mathrm{~g} / \text { day Ca orally. }\end{array}$ & $2 y$ & $\begin{array}{l}\text { Insignificant reduction of the BMD of the distal } \\
\text { radius and no significant increase in the BMD of the } \\
\text { lumbar spine in either group. }\end{array}$ \\
\hline Hughes et al ${ }^{19}$ & USA & $\begin{array}{l}389(176 \mathrm{M}, 213 \mathrm{~F}) \\
\text { aged } \geq 65 \mathrm{y}\end{array}$ & $\begin{array}{l}\text { Ca } 500 \mathrm{mg} / \text { day+Vit } \mathrm{D}_{3} 700 \mathrm{IU} / \text { day vs } \\
\text { placebo }\end{array}$ & 36 months & $\begin{array}{l}\text { Lower incidence of non-vertebral fracture among the } \\
\text { Ca-Vit D group as compared to the placebo group } \\
5.9 \% \text { vs } 12.9 \% \text { (RR: } 0.5,95 \% \text { CI }=0.2-0.9 ; \mathrm{p}=0.02 \text { ). }\end{array}$ \\
\hline $\begin{array}{l}\text { Baeksgaard et } \\
\text { al }^{20}\end{array}$ & Denmark & $\begin{array}{l}240 \mathrm{~F} \\
\text { aged } 58-67 \mathrm{y}\end{array}$ & $\begin{array}{l}1000 \mathrm{mg} / \text { day } \mathrm{Ca}+14 \mu \mathrm{g} / \text { day } \mathrm{Vit}_{3} \mathrm{D}_{3} \mathrm{vs} \text {. } \\
\text { placebo }\end{array}$ & $2 y$ & $\begin{array}{l}\text { Increase in lumbar spine BMD among the treatment } \\
\text { group at both } 1(\mathrm{p}<0.01) \text { and } 2 \mathrm{y}(\mathrm{p}<0.05) \text { compared } \\
\text { with the placebo. }\end{array}$ \\
\hline Krieg et al $^{21}$ & Switzerland & $\begin{array}{l}248 \mathrm{~F} \\
\text { aged } 62-98 \mathrm{y}\end{array}$ & $\begin{array}{l}440 \text { IU of Vit } \mathrm{D}_{3}+500 \mathrm{mg} \text { Ca twice daily } \\
\text { vs. control }\end{array}$ & $2 y$ & $\begin{array}{l}\text { Increase in } 25 \text {-hydroxyvitamin D by } 123 \%(\mathrm{p}<0.01) \text {, } \\
\text { a decrease in PTH by } 18 \%(\mathrm{p}<0.05) \text { and an increase } \\
\text { in BUA by } 1.6 \% \text { in treatment group. }\end{array}$ \\
\hline Ringe et al $^{22}$ & Germany & $\begin{array}{l}85 \text { patients }(55 \mathrm{M}, 30 \\
\mathrm{F}) \text { on glucocorticoid } \\
\text { induced osteoporosis } \\
\text { therapy }\end{array}$ & $\begin{array}{l}\text { Group A: } 1 \mu \mathrm{g} / \text { day alfacalcidol+500 } \\
\text { mg/day Ca } \\
\text { Group B: } 1000 \text { IU/day Vit D3+500 mg/day } \\
\text { Ca }\end{array}$ & $3 y$ & $\begin{array}{l}\text { Decrease in } 25 \text {-hydroxy vitamin D by } 51 \% \\
(\mathrm{p}<0.01) \text {, an increase in PTH by } 51 \%(\mathrm{p}<0.01) \text { and } \\
\text { a decrease in BUA by } 2.3 \% \text { in the control }(\mathrm{p}<0.01) \\
\text { No significant change of the lumber spine density } \\
\text { and back pain in the vit } \mathrm{D}_{3} \text { group after treatment. }\end{array}$ \\
\hline Pfeifer et $\mathrm{al}^{23}$ & Germany & $\begin{array}{l}148 \mathrm{~F} \text { (mean age } 74 \mathrm{y}) \\
\text { with } 25 \text { - } \\
\text { hydroxycholecalciferol } \\
\text { level }<50 \mathrm{nmol} / \mathrm{L}\end{array}$ & $\begin{array}{l}\text { Ca-Vit D group: } 1200 \mathrm{mg} \text { of } \mathrm{Ca}+800 \mathrm{IU} \text { of } \\
\text { Vit D } \\
\text { Ca mono group: } 1200 \mathrm{mg} / \text { day of } \mathrm{Ca}\end{array}$ & $1 \mathrm{y}$ & $\begin{array}{l}\text { Incidence of at least one fall: } 28 \% \text { in Ca-mono group } \\
\text { vs } 16 \% \text { in Ca-Vit } D \text { group ( } p=0.0373 \text { ) } \\
\text { Mean number of falls: } 0.45 \text { in the calcium mono and } \\
0.24 \text { in the Ca-Vit } D \text { group ( } p=0.0346) \text {. }\end{array}$ \\
\hline
\end{tabular}




\begin{tabular}{|c|c|c|c|c|c|}
\hline $\begin{array}{l}\text { Authors, } \\
\text { year (ref) }\end{array}$ & $\begin{array}{l}\text { Study } \\
\text { location }\end{array}$ & Subject & Treatment & Duration & Findings \\
\hline $\begin{array}{l}\text { Son and } \\
\text { Chun }^{24}\end{array}$ & Korea & $\begin{array}{l}69 \mathrm{~F} \text { with osteopenia } \\
\text { aged }>65 \mathrm{y}\end{array}$ & $\begin{array}{l}\text { Ca group }(1000 \mathrm{mg} / \text { day }) \text { Alphacalcidol } \\
\text { group }(0.5 \mu \mathrm{g} / \text { day }) \text { and Placebo }\end{array}$ & 10 months & $\begin{array}{l}\text { Significant increase in Ward's triangle BMD in the } \\
\text { both Ca-supplemented and alphacalcidol group } \\
(\mathrm{p}<0.05) \text {. }\end{array}$ \\
\hline Chapuy et $a^{25}$ & France & $\begin{array}{l}583 \mathrm{~F} \\
\text { mean age } 85.2 \mathrm{y}\end{array}$ & $\begin{array}{l}\text { Ca-Vit } D_{3} \text { fixed combination group: } \mathrm{Ca} \\
1200 \mathrm{mg} / \text { day+Vit } \mathrm{D}_{3} 800 \mathrm{IU} / \text { day, } \mathrm{Ca}-\mathrm{Vit} \\
\mathrm{D}_{3} \text { Separate combination group: Ca } 1200 \\
\text { mg/day+Vit } \mathrm{D} 800 \text { IU/day and placebo }\end{array}$ & 24 months & $\begin{array}{l}\text { The risk ratio for hip fracture in placebo group } \\
\text { compared with those in the both treatment group: } \\
1.69(95 \% \mathrm{CI}=0.96-3) \text {. }\end{array}$ \\
\hline Bischoff et $a^{26}$ & Switzerland & $\begin{array}{l}122 \mathrm{~F} \\
\text { mean age } 85.3 \mathrm{y}\end{array}$ & $\begin{array}{l}\mathrm{Ca}+\text { Vit Dgroup: } 1200 \mathrm{mg} / \text { day } \mathrm{Ca}+800 \\
\mathrm{IU} / \text { day cholecalciferol, Ca group: } 1200 \\
\mathrm{mg} / \text { day Ca }\end{array}$ & 12 weeks & $\begin{array}{l}\text { About } 45 \% \text { reduction of falls in the } \mathrm{Ca}+\mathrm{Vit} \mathrm{D} \text { group } \\
\text { as compared to Ca group }(\mathrm{p}<0.01) .\end{array}$ \\
\hline Doetsch et $\mathrm{al}^{27}$ & Denmark & $\begin{array}{l}30 \mathrm{~F} \\
\text { mean age } 78 \text { y } \\
\text { with non-displaced } \\
\text { PHF }\end{array}$ & $\begin{array}{l}800 \mathrm{IU} / \text { day } \mathrm{Vit} \mathrm{D}_{3}+1000 \mathrm{mg} / \text { day Ca vs. } \\
\text { placebo }\end{array}$ & 12 weeks & $\begin{array}{l}\text { BMD levels after } 12 \text { weeks were significantly higher } \\
\text { among the active group compared with the placebo } \\
(\mathrm{p}=0.02) \text {. }\end{array}$ \\
\hline $\begin{array}{l}\text { Harwood et } \\
\text { al }^{28}\end{array}$ & England & $\begin{array}{l}150 \mathrm{~F} \\
\text { with hip fracture }\end{array}$ & $\begin{array}{l}\text { Treatment group 1: single injection of } \\
300,000 \text { units of Vit } D_{2} \text {, Treatment group } \\
\text { 2: injected Vit } D_{2}+1 \mathrm{~g} / \text { day oral Ca, } \\
\text { Treatment group 3: } 800 \text { units/day oral Vit } \\
D_{3}+1 \text { g/day Ca, Placebo }\end{array}$ & $1 \mathrm{y}$ & $\begin{array}{l}\text { Neck of femur BMD, trochanter BMD and total hip } \\
\text { was } 2.7 \%, 3.2 \% \text { and } 3.5 \% \text { greater respectively than } \\
\text { the placebo. } \\
\text { Relative risk of fall in the supplemented groups was } \\
0.31(95 \% \mathrm{CI}=0.08-1.14 ; \mathrm{p}=0.11) \text { compared with } \\
\text { placebo. }\end{array}$ \\
\hline Larsen et $\mathrm{al}^{29}$ & Denmark & $\begin{array}{l}9605(\text { M 3834, F 5771) } \\
\text { aged } \geq 66 \text { y }\end{array}$ & $\begin{array}{l}\mathrm{Ca}+\mathrm{Vit} \mathrm{D} \text { group: } 1000 \mathrm{mg} / \mathrm{day} \mathrm{Ca}+400 \mathrm{IU} \\
\text { of Vit } \mathrm{D} \text {, Environmental and health } \\
\text { Program group, both intervention group } \\
\text { and control group }\end{array}$ & $3 y$ & $\begin{array}{l}16 \% \text { reduction in fracture incidence rate }(\mathrm{RR}: 0.84 \text {, } \\
\mathrm{CI}=0.72-0.98 ; \mathrm{p}<0.025) \text { among the Vit } \mathrm{D}-\mathrm{Ca} \text { group. }\end{array}$ \\
\hline Meier et $\mathbf{a l}^{30}$ & Germany & $\begin{array}{l}55(19 \mathrm{M}, 36 \mathrm{~F}) \\
\text { healthy adults } \\
\text { aged } 33-78 \mathrm{y}\end{array}$ & $\begin{array}{l}\text { Oral Vit } \mathrm{D}_{3} 500 \mathrm{IU} / \text { day }+ \text { Ca } 500 \mathrm{mg} / \text { day } \\
\text { vs. placebo }\end{array}$ & $2 y$ & $\begin{array}{l}\text { Significant increase in bone loss among the controls } \\
\text { as compared to treatment group (lumbar spine, } \\
\mathrm{p}<0.03 \text {; femoral neck, } \mathrm{p}<.05 \text { ). }\end{array}$ \\
\hline Grant et al $^{31}$ & England & $\begin{array}{l}5292(811 \mathrm{M}, 4481 \mathrm{~F}) \\
\text { aged } \geq 70 \text { y with low- } \\
\text { trauma-fracture }\end{array}$ & $\begin{array}{l}\text { Group 1: } 1000 \mathrm{mg} / \text { day } \mathrm{Ca} \text {, Group 2: } 800 \\
\text { IU/day Vit } \mathrm{D}_{3} \text {, Group 3: Ca } 1000 \\
\mathrm{mg} / \text { day+800 IU/day Vit } \mathrm{D}_{3} \text { and Placebo }\end{array}$ & 62 months & $\begin{array}{l}\text { No significant difference of incidence of new, low- } \\
\text { trauma fractures between the participants allocated } \\
\text { Ca and those who were not HR: } 0.94 \text { [ } 95 \% \mathrm{CI}=0.81- \\
\text { 1.09]; between group Vit } \mathrm{D}_{3} \text { and those who were not } \\
\text { HR: } 1.02[95 \% \mathrm{CI}=0.88-1.19] \text {; or between group of } \\
\text { combination treatment and those assigned placebo } \\
\text { HR: } 1.01[95 \% \mathrm{CI}=0.75-1.36]\end{array}$ \\
\hline $\begin{array}{l}\text { Porthouse et } \\
\text { al }^{32}\end{array}$ & England & $\begin{array}{l}3314 \mathrm{~F} \text { with one or } \\
\text { more risk factors for } \\
\text { hip fracture } \\
\text { mean age } 77 \mathrm{y}\end{array}$ & $\begin{array}{l}\mathrm{Ca} 1000 \mathrm{mg} / \text { day+Vit D } 800 \\
\text { IU/day+information leaflet on dietary Ca } \\
\text { intake and prevention of falls vs. leaflet } \\
\text { only (control group) }\end{array}$ & 25 months & $\begin{array}{l}\text { Clinical fracture rates were lower than expected in } \\
\text { both groups but did not significantly differ for all } \\
\text { clinical fractures (in supplemented group OR for } \\
\text { fracture } 1.01,95 \% \mathrm{CI}=0.71-1.43 \text { and OR for hip } \\
\text { fracture } 0.75,95 \% \mathrm{CI}=0.31-1.78 \text { ). }\end{array}$ \\
\hline
\end{tabular}




\begin{tabular}{|c|c|c|c|c|c|}
\hline $\begin{array}{l}\text { Authors, } \\
\text { year (ref) }\end{array}$ & $\begin{array}{l}\text { Study } \\
\text { location }\end{array}$ & Subject & Treatment & Duration & Findings \\
\hline Jackson et $\mathbf{a l}^{33}$ & USA & $\begin{array}{l}36,282 \text { post- } \\
\text { menopausal women } \\
\text { aged } 50-79 \mathrm{y}\end{array}$ & $\begin{array}{l}1000 \text { mg/day } \mathrm{Ca}+400 \mathrm{IU} / \text { day } \mathrm{Vit}_{3} \text { vs. } \\
\text { Placebo }\end{array}$ & $7 y$ & $\begin{array}{l}1.06 \% \text { higher hip bone density in the } \mathrm{Ca}+\mathrm{Vit} \mathrm{D} \\
\text { group than in the placebo group ( } \mathrm{p}<0.01) \text {; In the } \mathrm{Ca} \\
+\mathrm{Vit} \mathrm{D} \text { group, for hip fracture HR: } 0.88(95 \% \\
\mathrm{CI}=0.72-1.08) \text {, for clinical spine fracture HR: } 0.90 \\
(0.74-1.10) \text {, and for total fractures HR: } 0.96(0.91- \\
1.02)\end{array}$ \\
\hline $\begin{array}{l}\text { Bolton-Smith } \\
\text { et } \text { al }^{34}\end{array}$ & Scotland & $\begin{array}{l}244 \mathrm{~F} \\
\text { aged } \geq 60 y\end{array}$ & $\begin{array}{l}\text { Group 1: Placebo, Group 2: } 200 \mu \mathrm{g} / \text { day Vit } \\
\mathrm{K}_{1}, 3 \text {. Group 3: } 400 \mathrm{IU} / \text { day Vit } \mathrm{D}_{3}+1000 \\
\mathrm{mg} / \text { day Ca, Group 4: } 200 \mu \mathrm{g} / \text { day Vit } \\
\mathrm{K}_{1},+400 \mathrm{IU} / \text { day Vit } \mathrm{D}_{3}+1000 \mathrm{mg} / \text { day } \mathrm{Ca}\end{array}$ & $2 y$ & $\begin{array}{l}\text { Significant increase in BMD of } 0.8 \% / \mathrm{y}(\mathrm{p}<0.01) \text { and } \\
\text { in } \mathrm{BMC}(\mathrm{p}<0.01) \text { at the ultra-distal radius in the } \\
\text { combined Vit K and Vit D plus Ca group }\end{array}$ \\
\hline $\begin{array}{l}\text { Kukuljan et } \\
\text { al }^{35}\end{array}$ & Australia & $\begin{array}{l}180 \mathrm{M} \\
\text { aged } 50-79 y\end{array}$ & $\begin{array}{l}\text { Group 1: Exercise+fortified milk (1,000 } \\
\left.\text { mg/day Ca and } 800 \mathrm{IU} / \text { day Vit } \mathrm{D}_{3}\right) \text {, Group } \\
\text { 2: Exercise, Group 3: Fortified milk (1,000 } \\
\left.\text { mg/day Ca and } 800 \mathrm{IU} / \text { day Vit } \mathrm{D}_{3}\right) \text {, Group } \\
\text { 4: Control }\end{array}$ & 12 months & $\begin{array}{l}\text { About } 1.4-1.5 \% \text { increase in lumbar spine BMD in all } \\
\text { treatment groups than controls (all } \mathrm{p}<0.01) \\
\text { No main effects of fortified milk at any skeletal site }\end{array}$ \\
\hline $\begin{array}{l}\text { Salovaara et } \\
\text { al }^{36}\end{array}$ & Finland & $\begin{array}{l}3432 \mathrm{~F} \\
\text { aged } 65-71 \mathrm{y}\end{array}$ & $\begin{array}{l}800 \mathrm{IU} \text { of } \mathrm{D}_{3} \text { and } 1000 \mathrm{mg} \text { of } \mathrm{Ca} \text { as calcium } \\
\text { carbonate vs. control }\end{array}$ & $3 y$ & $\begin{array}{l}\text { Non-significant decreased in the risk of any fracture } \\
\text { and any non-vertebral fracture among treatment } \\
\text { group by } 17 \% \text { (HR: } 0.83,95 \% \text { CI } 61-1.12 \text { ) and by } \\
13 \% \text { (HR: } 0.87,95 \% \mathrm{CI}=0.63-1.19) \text {, respectively }\end{array}$ \\
\hline
\end{tabular}

Note: BMD: Bone mineral density, BUA: Broad band ultrasound attenuation, CI: Confidence interval, F: Female, HR: Hazard ratio, IU: International unit, M: Male, PTH: Parathyroid hormone, RR: Relative risk, y: Years. 
In the present review, an attempt has been made to provide comprehensive detail of the association of calcium and vitamin D supplementation on osteoporosis. From the above studies, it can be revealed that use of calcium and vitamin D supplementation may have a wide-ranging opportunity relating to the management and treatment of osteoporosis. There are a number of evidences which identified that combined supplementation of calcium and vitamin D treatment is significant in the reduction of osteoporosis but some studies are also found to be controversial. However, further comprehensive research is required to investigate the associations between supplementation of calcium and vitamin $\mathrm{D}$ and identify the mechanisms behind the reduction of osteoporosis.

\section{CONCLUSION}

Osteoporosis and bone loss with an increased risk of fracture is a matter to worry for patients and health care providers. With the increment of age, the long-term upshots of osteoporosis including pain, disability, dependency and institutionalized care will become more prevalent with enormous medical and heavy personnel burden on both the patient's and nation's economy. Osteoporosis can be prevented through an early diagnosis before fractures occur and assessment of BMD, and a preliminary treatment regimen will also be beneficial. Also, efforts to avert osteoporosis and bone loss should commence with appropriate education about a healthy lifestyle, including optimal calcium and vitamin D intake, and exercise from adolescence. This education should continue throughout life, with special attention at the time of elevated bone loss such as the menopause transition.

The present study reviews calcium and vitamin $\mathrm{D}$, the cornerstones of bone health. Even though the dietary sources of both nutrients are available, most people do not get adequate amounts for maintaining proper bone health. Additionally, vitamin D synthesis from the skin has been restricted by the profound consciousness of the harmful effects of sunlight. Luckily, supplements are attainable which can supply the body with the necessary amounts for proper bone health.

It is widely recognized that there are genetic, environmental, lifestyle and dietary determinants of risk of osteoporosis, as well as interactions between them. In the present review, combined calcium and vitamin D supplementation has been found to be significantly associated with reduced total bone and hip fractures, improved overall bone health and BMD in most of the studies. But, some RCTs also found no significant positive effect of calcium and vitamin D supplementation on overall bone health. However, due to these inconsistencies of the findings, making any consensus about the effect of supplementation of calcium and vitamin D on osteoporosis is still very crucial. Therefore, to get a better understanding of this area of knowledge, further research should be carried out on fundamental aspects of bone biology, taking into account progress in molecular genetics, and factors influencing the acquisition of bone mass during growth and bone loss during adult life to generate uncontroversial evidence.

\section{Funding: No funding sources \\ Conflict of interest: None declared \\ Ethical approval: None required}

\section{REFERENCES}

1. Chen LR, Wen YT, Kuo CL, Chen KH. Calcium and vitamin $\mathrm{D}$ supplementation on bone health: current evidence and recommendations. Int $\mathrm{J}$ Gerontol. 2014;8(4):183-8.

2. WHO. Prevention and management of osteoporosis. World Health Organization: Geneva, Switzerland; 2003.

3. WHO. Assessment of fracture risk and its application to screening for postmenopausal osteoporosis. World Health Organization: Geneva, Switzerland; 1994.

4. Sozen T, Ozisik L, Basaran NC. An overview and management of osteoporosis. Eur J Rheumatol. 2017;4(1):46-56.

5. Reginster JY, Burlet N. Osteoporosis: a still increasing prevalence. Bone. 2006;38(2):4-9.

6. Wright NC, Looker AC, Saag KG, Curtis JR, Delzell ES, Randall S, et al. The recent prevalence of osteoporosis and low bone mass in the United States based on bone mineral density at the femoral neck or lumbar spine. J Bone Miner Res. 2014;29(11):2520-6.

7. Watts NB, Bilezikian JP, Camacho PM, Greenspan SL, Harris ST, Hodgson SF, et al. American Association of Clinical Endocrinologists Medical Guidelines for Clinical Practice for the diagnosis and treatment of postmenopausal osteoporosis: executive summary of recommendations. Endocr Pract. 2010;16(6):1016-9.

8. Lau EM, Lee JK, Suriwongpaisal P, Saw SM, Das De S, Khir A, et al. The incidence of hip fracture in four Asian countries: the Asian Osteoporosis Study (AOS). Osteoporos Int. 2001;12(3):239-43.

9. Weaver CM. Calcium supplementation: is protecting against osteoporosis counter to protecting against cardiovascular disease? Curr Osteoporos Rep. 2014;12(2):211-8.

10. Laird E, Ward M, McSorley E, Strain JJ, Wallace J. Vitamin D and bone health: potential mechanisms. Nutrients. 2010;2(7):693-724.

11. Burge R, Dawson-Hughes B, Solomon DH, Wong JB, King A, Tosteson A. Incidence and economic burden of osteoporosis-related fractures in the United States, 2005-2025. J Bone Miner Res. 2007;22(3):465-75.

12. Bailey RL, Dodd KW, Goldman JA, Gahche JJ, Dwyer JT, Moshfegh AJ, et al. Estimation of total 
usual calcium and vitamin D intakes in the United States. J Nutr. 2010;140(4):817-22.

13. Wallace TC, Reider C, Fulgoni VL. Calcium and vitamin $\mathrm{D}$ disparities are related to gender, age, race, household income level, and weight classification but not vegetarian status in the United States: Analysis of the NHANES 2001-2008 data set. J Am Coll Nutr. 2013;32(5):321-30.

14. Jowsey J, Riggs BL, Kelly PJ, Hoffmann DL. Effect of combined therapy with sodium fluoride, vitamin $\mathrm{D}$ and calcium in osteoporosis. Am $\mathbf{J}$ Med. 1972;53(1):43-9.

15. Riggs BL, Jowsey J, Kelly PJ, Hoffman DL, Arnaud CD. Effects of oral therapy with calcium and vitamin $\mathrm{D}$ in primary osteoporosis. $\mathrm{J}$ Clin Endocrinol Metab. 1976;42(6):1139-44.

16. Inkovaara J, Gothoni G, Halttula R, Heikinheimo R, Tokola O. Calcium, vitamin D and anabolic steroid in treatment of aged bones: double-blind placebocontrolled long-term clinical trial. Age Ageing. 1983;12(2):124-30.

17. Chapuy MC, Arlot ME, Duboeuf F, Brun J, Crouzet B, Arnaud S, et al. Vitamin D3 and calcium to prevent hip fractures in elderly women. $\mathrm{N}$ Engl J Med. 1992;327(23):1637-42.

18. Eriksson SA, Lindgren JU. Combined treatment with calcitonin and 1,25-dihydroxyvitamin D3 for osteoporosis in women. Calcif Tissue Int. 1993;53(1):26-8.

19. Dawson-Hughes B, Harris SS, Krall EA, Dallal GE. Effect of calcium and vitamin D supplementation on bone density in men and women 65 years of age or older. N Engl J Med. 1997;337(10):670-6.

20. Baeksgaard L, Andersen KP, Hyldstrup L. Calcium and vitamin D supplementation increases spinal BMD in healthy, postmenopausal women. Osteoporos Int. 1998;8(3):255-60.

21. Krieg MA, Jacquet AF, Bremgartner M, Cuttelod S, Thiebaud D, Burckhardt P. Effect of supplementation with vitamin D3 and calcium on quantitative ultrasound of bone in elderly institutionalized women: a longitudinal study. Osteoporos Int. 1999;9(6):483-8.

22. Ringe JD, Coster A, Meng T, Schacht E, Umbach R. Treatment of glucocorticoid-induced osteoporosis with alfacalcidol/calcium versus vitamin D/calcium. Calcif Tissue Int. 1999;65(4):337-40.

23. Pfeifer M, Begerow B, Minne HW, Abrams C, Nachtigall D, Hansen C. Effects of a short-term vitamin $\mathrm{D}$ and calcium supplementation on body sway and secondary hyperparathyroidism in elderly women. J Bone Miner Res. 2000;15(6):1113-8.

24. Son SM, Chun YN. Effect of oral therapy with alphacalcidol or calcium in Korean elderly women with osteopenia and low dietary calcium. Nutr Res. 2001;21(10):1347-55.

25. Chapuy MC, Pamphile R, Paris E, Kempf C, Schlichting M, Arnaud S, et al. Combined calcium and vitamin D3 supplementation in elderly women: confirmation of reversal of secondary hyperparathyroidism and hip fracture risk: the Decalyos II study. Osteoporos Int. 2002;13(3):25764.

26. Bischoff HA, Stahelin HB, Dick W, Akos R, Knecht M, Salis C, et al. Effects of vitamin D and calcium supplementation on falls: a randomized controlled trial. J Bone Miner Res. 2003;18(2):34351.

27. Doetsch AM, Faber J, Lynnerup N, Watjen I, Bliddal H, Danneskiold-Samsoe B. The effect of calcium and vitamin D3 supplementation on the healing of the proximal humerus fracture: a randomized placebo-controlled study. Calcif Tissue Int. 2004;75(3):183-8.

28. Harwood RH, Sahota O, Gaynor K, Masud T, Hosking DJ. A randomised, controlled comparison of different calcium and vitamin D supplementation regimens in elderly women after hip fracture: The Nottingham Neck of Femur (NONOF) Study. Age Ageing. 2004;33(1):45-51.

29. Larsen ER, Mosekilde L, Foldspang A. Vitamin D and calcium supplementation prevents osteoporotic fractures in elderly community dwelling residents: a pragmatic population-based 3-year intervention study. J Bone Miner Res. 2004;19(3):370-8.

30. Meier C, Woitge HW, Witte K, Lemmer B, Seibel MJ. Supplementation with oral vitamin D3 and calcium during winter prevents seasonal bone loss: a randomized controlled open-label prospective trial. J Bone Miner Res. 2004;19(8):1221-30.

31. Grant AM, Avenell A, Campbell MK, McDonald AM, MacLennan GS, McPherson GC, et al. Oral vitamin D3 and calcium for secondary prevention of low-trauma fractures in elderly people (Randomised Evaluation of Calcium Or vitamin D, RECORD): a randomised placebo-controlled trial. Lancet. 2005;365(9471):1621-8.

32. Porthouse J, Cockayne S, King C, Saxon L, Steele E, Aspray T, et al. Randomised controlled trial of calcium and supplementation with cholecalciferol (vitamin D3) for prevention of fractures in primary care. BMJ. 2005;330(7498):1003.

33. Jackson RD, LaCroix AZ, Gass M, Wallace RB, Robbins J, Lewis CE, et al. Calcium plus vitamin D supplementation and the risk of fractures. N Engl J Med. 2006;354(7):669-83.

34. Bolton-Smith C, McMurdo ME, Paterson CR, Mole PA, Harvey JM, Fenton ST, et al. Two-year randomized controlled trial of vitamin K1 (phylloquinone) and vitamin D3 plus calcium on the bone health of older women. J Bone Miner Res. 2007;22(4):509-19.

35. Kukuljan S, Nowson CA, Bass SL, Sanders K, Nicholson GC, Seibel MJ, et al. Effects of a multicomponent exercise program and calcium-vitaminD3-fortified milk on bone mineral density in older 
men: a randomised controlled trial. Osteoporos Int. 2009;20(7):1241-51.

36. Salovaara K, Tuppurainen M, Karkkainen M, Rikkonen T, Sandini L, Sirola J, et al. Effect of vitamin $\mathrm{D}(3)$ and calcium on fracture risk in 65 - to 71-year-old women: a population-based 3-year randomized, controlled trial--the OSTPRE-FPS. J Bone Miner Res. 2010;25(7):1487-95.

Cite this article as: Shill LC, Purba NH, Sultana M, Hasan T, Rahman M, Sultana N. An update on osteoporosis research: effect of calcium plus vitamin D supplementation. Int J Community Med Public Health 2019;6:4120-8. 